LEON NIEŚCIOR, WARSZAWA

ORCID: 0000-0003-4988-9667

\title{
NAMIĘTNOŚCI I WALKA Z NIMI WEDŁUG MARKA EREMITY
}

Marek Eremita pisze w okresie, w którym myśl ascetyczna dysponuje już sporą tradycją. W nauce o namiętnościach i pracy nad nimi nie musi definiować wielu pojęć. Posługuje się chętnie słowem $\pi \alpha ́ \theta$ os, które najczęściej ma dla niego moralne znaczenie. W naszej

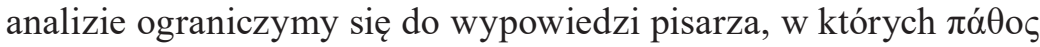
występuje formalnie.

\section{Geneza namiętności}

Słowo „geneza" dobrze oddaje pierwszy przedmiot naszego dociekania, który obejmuje zarówno czynniki, jak i sposób powstania oraz rozwoju namiętności.

Nasz autor stwierdza, że nieznajomość przyczyn namiętności prędko prowadzi do upadku. ${ }^{1}$ Wnikanie w przyczyny nie jest więc zabiegiem czysto teoretycznym, ale ma znaczenie praktyczne. Właściwie postawiona diagnoza skłania do podjęcia odpowiednich środków. W charakterystyczny dla siebie sposób pisarz mówi często o miłowaniu bądź nienawidzeniu ,przyczyn” (aỉías) namiętności, czyli - w zasadzie - ich przedmiotu. Kto poddaje się tym przyczynom, poddaje się namiętnościom, nawet wbrew swojej woli. Kto nienawidzi namiętności, usuwa ich przyczyny. ${ }^{2}$ Nie sposób myśleć o namiętnościach, nie mając upodobania w ich przyczynach. $\mathrm{Na}$ przykład ten, komu nie zależy na uznaniu ludzkim, co więcej, jest

Zob. Mare k E r e mit a, De lege spirituali, PG 65, 78.

2 Zob. te n ż e, De his qui putant se ex operibus iustificari, 111, PG 65, 945. 
mu obojętna wzgarda, nie będzie dążył do chwały ludzkiej, która jest przyczyną próżności. ${ }^{3}$

Czynników wywołujących schorzenie moralne należy szukać przede wszystkim w samym człowieku. Bezpośrednią ich przyczyną nie są zewnętrzne okoliczności, jak na przykład pomyślność doczesna. Sprawiedliwi Starego Przymierza, jak Abraham, Hiob czy Dawid, byli „beznamiętnie bogaci” i dlatego podobali się Bogu, podczas gdy inni nie mają bogactw, ale żywią namiętność, pragnąc je usilnie nabyć. ${ }^{4}$

Marek Mnich usiłuje wskazać na wspólną przyczynę namiętności, jednak nie zatrzymuje się dłużej nad tą kwestią. Odwołuje się do stwierdzenia św. Pawła, że korzeniem wszelkiego zła jest chciwość (1Tm 6,10), ale i ta istnieje dzięki innym namiętnościom, a mianowicie dzięki próżności i rozkoszy. ${ }^{5}$ Podobnie stwierdza gdzie indziej, że przyczyną wszelkiej złości jest próżność i rozkosz. Kto nimi nie wzgardzi, nie pokona namiętności. ${ }^{6}$ Wydaje się, że wspólnym mianownikiem dla schorzeń moralnych pozostaje właśnie skłonność do poszukiwania przyziemnych przyjemności. Wspólną „matką” na-

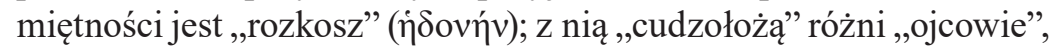
czyli namiętności. ${ }^{7}$ Jeśli nawet jakaś namiętność została zwalczona, to skłonność do przyjemności (†் $\delta v \pi \alpha \theta \varepsilon i ́ \alpha \varsigma)$ może ponownie obudzić myśli o dawnych rzeczach. ${ }^{8}$

Autor wskazuje też na inne zjawiska dające podstawę do zadomowienia się zła we wnętrzu ludzkim. Najgłębszymi namiętnościami duszy jest zapomnienie dobrych myśli, lekkomyślność i nieświadomość

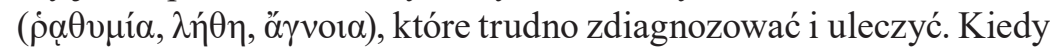
człowiek oddaje się przesadnej aktywności, namiętności te zaciemniają ducha i sprawiają, że zagnieżdżają się także inne, powodujące zanik bojaźni Bożej i zaniedbanie dobra. ${ }^{9}$ Te trzy dają podstawę

\footnotetext{
Zob. tamże, 114.

Zob. t e n ż e, Consultatio intellectus cum sua ipsius anima, PG 65, 3.

Zob. t e n ż e, De lege spirituali, 103.

Zob. tami̇e, 102.

Zob. tamie, 100.

Zob. te n ż e, De baptismo, 11, PG 65, 1016.

Zob. te n ż e, Ad Nicolaum praecepta animae salutaria, PG 65, 10.
} 
wszystkim innym namiętnościom..$^{10}$ Dla Marka panny nieroztropne (Mt 25, 1-13), które zabrały trochę oliwy na spotkanie z oblubieńcem, oznaczają tych, którzy zachowują pewną cnotliwość i poprawność postępowania, ale pod wpływem niedbałości, lekkomyślności i niewiedzy zatracili troskę o wewnętrzną czystość duszy. Nie wejrzeli przezornie w głąb naczynia duszy, nie zauważyli tam namiętności. ${ }^{11}$

Zapomnienie, lekkomyślność i nieświadomość trudno nazwać w sensie ścisłym namiętnościami, jak czyni to nasz autor. Są to raczej elementy ludzkiej postawy, która prowadzi do namiętności. Chociaż na ogół Marek posługuje się utartym pojęciem $\pi \alpha ́ \theta$ os, to jednak, jak widzimy, nie przykłada zbyt wielkiej wagi do precyzji pojęć. Jednak, wskazanie na trzy składniki konstytuujące każdą namiętność wydaje się cennym wkładem w starożytną myśl ascetyczną. O ile skłonność do przyjemności jest źródłem namiętności wrodzonym człowiekowi, to wyżej wspomniane uchybienia zdają się jego osobistą winą w powstaniu moralnego schorzenia. Według naszej orientacji, nikt przed Markiem Eremitą nie łączył owych trzech braków moralnych w jedno źródło, z którego wypływa każda namiętność. Tymczasem po nim pojawiają się, wyraźnie przejęte od niego, w kompilatorskim dziełku anonimowego autora, zatytułowanym De virtutibus et vitiis. ${ }^{12}$ Warto podkreślić, że dziełko to, publikowane pod imieniem takich autorytetów, jak Efrem Syryjski czy Jan Damasceński, było poczytne w środowisku bizantyjskim, a ok. 1000 r. zostało przeredagowane przez być może Stefana z Nikomedii pod nazwą Syntagma ad quemdam politicum. ${ }^{13}$ Razem z popularyzacją wiedzy o namiętnościach w chrześcijaństwie wschodnim przekazywano niektóre myśli Marka Eremity na ten temat.

Zob. tamże, 12; tamże, 3.

1 Zob. tamże, 4.

12 Zob. P s e u d o-J a n D a m a s e ń s k i, De virtutibus et vitiis (fragmenta),

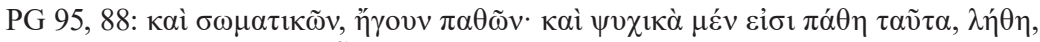

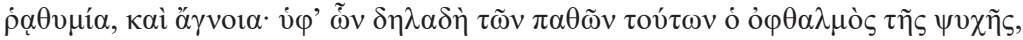

13 Zob. D. K r a u s m ü 11 e r, Religious Instruction for Laypeople in Byzantium: Stephen of Nicomedia, Nicephorus Ouranos, and the Pseudo-Athanasian Syntagma ad quendam politicum, Byzantion 2007, s. 239-250. 
Szukając przyczyny namiętności, w pewnej dłuższej wypowiedzi autor zdaje się sięgać do samego sedna sprawy. Zastanawia się mianowicie, dlaczego ludzie różnią się w sposobie myślenia i postępowania. Na to pytanie odpowiada w sposób opisowy. Nie wszyscy jednakowo znają naukę Bożą, nie wszyscy w jednakowym czasie, w jednakowych czynach, w jednakowy sposób odrzucają ludzką chwałę i upodobanie w przyjemnościach. Czynią to w zależności od tego, na ile wierzą w Boga, na ile pokładają nadzieję w przyszłych dobrach. Szukają własnej mądrości, a nie tej, która bierze się z wiary w Chrystusa i wyraża się w praktykowaniu przykazań. Nie troszczą się o to, by przez pokorę serca usuwać niewłaściwe myśli, raczej przez ukryte upodobanie w przyjemności zabiegają o chwałę ludzką, by podobać się ludziom. Ulegając pysze, chcą pokazywać innym swoje zwycięstwa i sukcesy. Przez to pozwalają, by rosły myśli pełne żądz, a przez nie różne namiętności. Dlatego w gruncie rzeczy niczego nie osiągają. Autor odwołuje się do sumień owych ludzi: Dlaczego nie starają się bronić przed takimi złymi myślami? Jeśli nawet bez winy ulegają tym myślom, to dając im posłuch nie słuchają słowa Bożego. Bóg staje się dla nich niewiarygodny. To przez czyn, słowo i myśl codziennie sprowadzają na siebie różne namiętności. Jeśli tak je kochają, jak gdyby były dobrodziejami, a nie wrogami, to jakim sposobem przeszkodzą ich wtargnięciu do wnętrza? Kiedy z kolei przyjmą pierwszą złą myśl, ta sprowadzi nieuchronnie następne. ${ }^{14}$

Namiętności to cielesne i nierozumne mechanizmy zła, którym dusza uległa i dała się pociągnąć oraz zniewolić. Taki zgubny proces ma swoje etapy: przywoływanie złych myśli - złe nad nimi

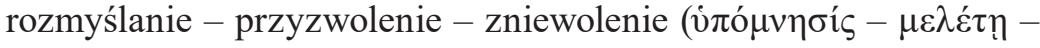

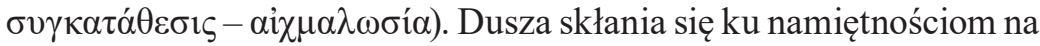
skutek wcześniejszych skłonności i przyzwyczajeń. ${ }^{15}$ Jeśli zauważy się, że żądze zostały obudzone i skłaniają do namiętności, to trzeba

14 Zob. Marek Eremita, De baptismo, 14.

15 Zob. t e n ż e, Ad Nicolaum praecepta animae salutaria, 1, 1029; nt. rozwoju zła prowadzącego do zniewolenia moralnego człowieka w myśli Marka Eremity zob. I. Z a j c e v, Svjatootečeskoe učenie o glavnych momentach postepennogo 
wiedzieć, że duch już wcześniej szukał ich przedmiotu, obrócił swoje pragnienia w czyn i zaszczepił je w sercu. ${ }^{16}$ Jak chmura nie najdzie bez wcześniejszego powiewu wiatru, tak namiętność nie powstanie bez wcześniejszej myślil. ${ }^{17}$

Zatem w człowieku tkwi przyczyna powstania i rozwoju namiętności, a dokładnie w jego umyśle, woli i uczuciach. Skłonność do przyjemności wzbudza materię odnośnych myśli i powoduje im uległość. Proces ten nasila się, a człowiek coraz bardziej słabnie w wierze, szukając dobra poza Bogiem. W pewnym miejscu Marek Eremita rozpatruje sprawczość woli ludzkiej w kontekście chrztu. Jeśli po chrzcie zostaniemy opanowani przez jakiś grzech, to nie z powodu niedoskonałości chrztu, ale dlatego że dobrowolnie lekceważyliśmy jakieś przykazanie i ulegliśmy złym przyjemnościom. ${ }^{18}$ Z nauki Marka wynika wniosek, że kto grzeszy po chrzcie, grzeszy na skutek osobistej winy, a nie z powodu istnienia jakiejś struktury zła będącej pozostałością po grzechu pierworodnym. ${ }^{19}$ Także i złe myśli nie są pozostałością grzechu Adama, ale pochodzą z naszej wolnej woli, z naszych złości. ${ }^{20}$ Jeśli z kolei mamy władzę nad namiętnościami, to na podstawie własnej woli, a nie czegoś innego. ${ }^{21}$

$\mathrm{Z}$ niektórych wypowiedzi autora wyłania się charakterystyka namiętności. Nie znajdujemy pełnego opisu tego zjawiska, lecz pojedyncze uwagi. Namiętności są postaciami zła rozlewającymi się we wnętrzu serca. ${ }^{22}$ Jak wiemy, starożytni pisarze chrześcijańscy,

razvitija grecha (sv. Ioann Lestvičnik, sv. Ioann Kassian, sv. Diadoch i sv. Mark Podvižnik), Moskau 1959 (msp).

16 Zob. Mare k E r e m it a, De lege spirituali, 180.

17 Zob. tamże, 181.

18 Zob. te n ż e, De baptismo, 2.

19 Zob. O. H e s s e, Der Streit über die Wirkung der Taufe im frühen Mönchtum bei Makarios/Symeon, Markos Eremites und den Messalianern, w: D. He $11 \mathrm{~h} \mathrm{ol} \mathrm{m}$ $\mathrm{i}$ in. (red.), Ablution, Initiation, and Baptism: Late Antiquity, Early Judaism, and Early Christianity, Berlin-Boston 2011, s. 1326.

20 Zob. tamże, s. 1323.

${ }_{21}$ Zob. Marek Eremit a, De baptismo, 2.

22 Zob. te n ż e, Ad Nicolaum praecepta animae salutaria, 1. 
idąc za antyczną filozofią, dwojako interpretowali namiętność: jako zniewolenie, chorobę moralną człowieka, którą trzeba wykorzenić, albo jako popęd, neutralną skłonność natury do czegoś, której nie da się wyzbyć, ale można ją opanować. ${ }^{23}$ Bez wątpienia, Marek Eremita reprezentuje ten pierwszy sposób rozumienia namiętności. W pewnym miejscu autor stwierdza, że jest jedenaście grzesznych namiętności. Jeśli z własnej woli umiłuje się jedną z nich, to ona wypełni miejsce wszystkich pozostałych. ${ }^{24} \mathrm{~W}$ odróżnieniu od stałego katalogu ośmiu głównych namiętności, wyróżnionych przez Ewagriusza z Pontu, lista różnych chorób moralnych u Marka Eremity jest dłuższa. Liczba jedenaście jest raczej przykładowa, ponieważ gdzie indziej występują inne liczby. W pewnym miejscu autor wymienia nawet trzydzieści dwie namiętności. ${ }^{25}$

Mnich wskazuje na trudność w rozpoznaniu np. próżności. Ludzkie uznanie pozostaje atrakcyjne i dlatego namiętność próżnej chwały staje się z trudem zauważalna przez tego, kto jej ulega. Inne namiętności skłaniają na ogół do ukorzenia się, podczas gdy ta ukrywa się pod pozorami pobożności i trudno jest zidentyfikować mechanizmy jej kuszenia. ${ }^{26}$ Nieraz nawet za pobożnym słowem kryje się chęć przedstawienia próżności jako czegoś dobrego. Różne ścieżki zła wiążą się ze sobą i spotykają w próżności: niewiara (matka wszystkich), zazdrość, nienawiść, rywalizacja, podstęp, kłótliwość, obłuda, stronniczość, pozoranctwo, potwarz, kłamstwo. Na przykład człowiek podstępny gani kogoś, by siebie wyeksponować; kiedy wygłasza mowę przed sądem, czyni to nie w imię sprawiedliwości, ale w celu odwetu; pomawia anonimowo, aby ukryć siebie jako sprawcę pomówienia; szuka korzyści i służy innym, aby zaspokoić głód uznania itp. ${ }^{27}$ Czasem jedna namiętność wypiera drugą. Może tak być, że

23 Zob. K. T. W a r e, The meaning of Pathos in Abba Isaias and Theodoret of Cyrus, Studia Patristica 20/1989, s. 315-322.

${ }_{24}$ Zob. Mare k E re mit a, De lege spirituali, 136.

25 Zob. te n ż e, Ad Nicolaum praecepta animae salutaria, 4.

26 Te n ż e, Disputatio cum quodam causidico, 9.

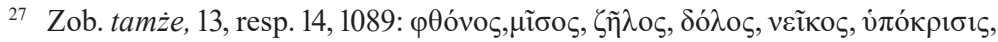

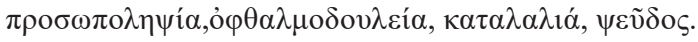




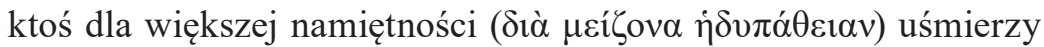
inną, słabszą. Podejmuje trud nadaremny, jeśliby inni go chwalili. ${ }^{28}$

Często podkreślanym przez pisarza zjawiskiem jest odradzanie się namiętności. Kiedy duch zmężnieje, a dusza odstąpi od przejściowej skłonności, serce doznaje udręki, pociągane przez ducha i namiętność. ${ }^{29}$ Mimo uprawianej ascezy, nadal dają znać o sobie namiętności ciała w wyniku prawa grzechu, które przeciwstawia się prawu naszego ducha $(\mathrm{Rz} 7,23) .{ }^{30}$ Kiedy już ktoś w sposób stały odrzuca namiętności, o których zapomniał dzięki Duchowi Świętemu, Zły na nowo je podsuwa. Jeśli już ktoś jest czysty i szczerze nienawidzi namiętności, przejściowo może doznać ciemności z powodu nadchodzących pokus. Kto jednak nie jest czysty i dalej szuka przyjemności, w takim owa pokusa budzi dawną słabość. ${ }^{31}$ Jak ucisk przychodzący w najmniej odpowiednią porę, czyli „w zimie albo w szabat" (Mt 24, 20), tak rewolta namiętności ogarnia ciało człowieka w starszym wieku czy duszę poświęconą Bogu. ${ }^{32}$

Między tym, co człowiek czuje i myśli, a tym, co czyni, zachodzi ścisły związek. Na pewnym etapie namiętności nie wychodzą poza zakres wewnętrzny, później jednak ujawniają się także na zewnątrz. W tym sensie jedne namiętności przyjmują kształt różnych myśli, a inne - czynów, jeśli nawet same kształty i obrazy się zmieniają. ${ }^{33} \mathrm{Na}$ przykład przejawem próżności jest poszukiwanie pochwały, a upodobania w przyjemności - narzekanie na przychodzące utrapienie. ${ }^{34}$ Nieraz namiętności wpływają na postępowanie nie wprost, ale pośrednio. Są ludzie, którzy wprawdzie spełniają na zewnątrz przykazania, ale ulegają wewnętrznie namiętności i przez złe myśli udaremniają swoje dobre czyny. ${ }^{35}$

\footnotetext{
28 Zob. te n ż e, De lege spirituali, 101, 917.

29 Zob. te n ż e, De his qui putant se ex operibus iustificari, 68.

30 Zob. t e n ż e, Ad Nicolaum praecepta animae salutaria, 1.

31 Zob. t e n ż e, De his qui putant se ex operibus iustificari, 140.

32 Zob. tamże, 70.

33 Zob. te n ż e, De lege spirituali, 179.

34 Zob. tamie, 144.

35 Zob. tami̇e, 170.
} 
Skutki namiętności były często przedmiotem uwagi starożytnych pisarzy ascetycznych. Marek Eremita wskazuje za innymi na konsekwencje wad: zniewolenie woli i zaciemnienie umysłu. Gdy namiętność nakłoni do czynu, opanowując wolę, to w tym, kto jej ulegnie, budzi się nawet i wbrew jego woli. ${ }^{36}$ Umysł doznaje zaciemnienia przez chciwość, próżność i rozkosz. ${ }^{37} \mathrm{Na}$ skutek namiętności widok pięknej kobiety natychmiast budzi cielesną żądzę. ${ }^{38}$ Zgubne oddziaływanie namiętności autor ilustruje przykładem gniewu. Stan taki powoduje kłótnie z braćmi. Nagromadzone złe wspomnienia uniemożliwiają czystą modlitwę, a umysł prowadzą do niewoli. Kształtują „zwierzęce” myśli o współbracie, który ma przecież taką samą duszę, poddając zagniewanego działaniu złych duchów i prowadząc jego umysł do smutku, zwątpienia czy lekkomyślności. ${ }^{39}$ Namiętność gniewu pustoszy duszę, mąci i zaciemnia, upodabniając człowieka do zwierzęcia. ${ }^{40}$

Autor opisuje gniew za pomocą obrazu drzewa i domu. Namiętność tę wspiera pycha, która czyni ją wprost niezniszczalną. Jest podobna do wody, która nawadnia diabelskie drzewo złożone z gory-

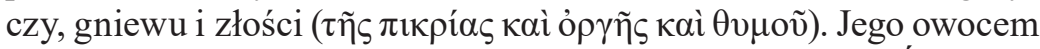

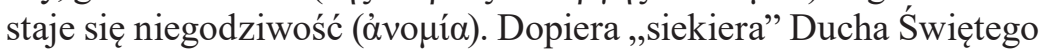
wycina drzewo i wrzuca do ognia (Mt 3, 10 par.), i unicestwia. Takiego człowieka można porównać do domu złożonego z wielu kamieni, którymi są nazbierane wspomnienia różnych myśli i czynów. ${ }^{41}$

\section{Walka z namiętnościami}

Autor poświęca dużo miejsca walce z namiętnościami. I w tym aspekcie brakuje u naszego pisarza systematycznej refleksji, jednak niektóre jego uwagi dostarczają subtelnych wskazań. ${ }^{42}$

36 Zob. te n ż e, De his qui putant se ex operibus iustificari, 78.

37 Zob. te n ż e, De lege spirituali, 103.

38 Zob. te n ż e, Ad Nicolaum praecepta animae salutaria, 10.

39 Zob. tamże, 3.

40 Zob. tamże, 8.

41 Zob. tamie, 1041.

42 Nt. wyzwolenia się z wewnętrznej niewoli i podążania ku duchowej wolności zob. I.-A. K h a 1 i fé, L'antropologie théologique de Marc l'Ermite. De l'esclavage intérieur à la liberté spirituelle, Roma 1949. 
Ważny jest ogólny styl życia nastawiony na ascezę. Kto zajmuje się rzemiosłem wojennym, nie para się innymi przyziemnymi zajęciami $(2 \mathrm{Tm} 2,4)$. Tak samo ten, kto chce zwyciężyć namiętności i daje się pochłonąć różnym zajęciom, podobny jest do tego, kto chce gasić pożar plewami. ${ }^{43}$ Autor pochwala adresata, że podejmuje walkę duchową przez wstrzemięźliwość, powściągliwość, czuwanie nocne i żarliwą modlitwę. ${ }^{44}$ Pewnemu adresatowi zaleca pielęgnowanie życia bezżennego i czystości. ${ }^{45}$ Przez częstą modlitwę, czuwanie, skruchę i wyznanie winy zaczyna się przemiana, otrzeźwienie, oświecenie dzięki Bożemu poznaniu. ${ }^{46}$

Mnich akcentuje czujność wobec pierwszych natarć zła. Człowiek mógł prosić Boga, gdy zło było jeszcze małe, aby je oddalił, a jednak tego nie uczynił, ponieważ za nic miał tę drobną rzecz, nie wiedząc, że małe prowadzi do większego, i to zarówno pod względem dobra, jak i zła. ${ }^{47}$ Tylko przy pierwszej myśli diabeł może podpowiadać zły czyn, aby badać głębię naszego wnętrza, to do czego się skłania.48 Ostateczna decyzja należy do człowieka. Ważne więc, żeby Złemu nie pozwolić na więcej. Potrzebna jest stanowczość w odrzuceniu podszeptu zła. Marek Eremita zachęca do tego, by „nienawidzić” namiętności. Na ogół krótko zatrzymujemy się przy tym, czego nienawidzimy, natomiast jesteśmy w stanie zatrzymać się dłużej w myślach przy tym, co kochamy. Jeśli nienawidzimy jakiejś namiętności, szybko odchodzą myśli z nią związane. Jeśli coś jednak trwa dłużej, mimo że tego nienawidzimy, to z tej racji, że wcześniej to nas pociągało. ${ }^{49}$ Cnota jest przeciwieństwem namiętności, ${ }^{50}$ zatem dawne przylgnięcie do słabości należy zastąpić dążeniem do cnoty.

\footnotetext{
43 Zob. Mare k E r e m it a, De lege spirituali, 109.

44 Zob. t e n ż e, Ad Nicolaum praecepta animae salutaria, 1.

45 Zob. tamże, 7.

46 Zob. tami̇e, 3.

47 Zob. te n ż e, De paenitentia, 9.

48 Zob. te n ż e, De baptismo, 11.

49 Zob. tamże, 11.

50 Zob. te n ż e, Disputatio cum quodam causidico, 11, resp. 10.
} 
Na ogół człowiek został już w przeszłości dotknięty przez jakąś chorobę duszy. Marek Eremita określa tryb życia będącego walką z namiętnościami słowem ,ppokuta”. To, co utrzymuje na dobrej drodze, to wysiłek ekspiacji i nawrócenia. Pokuta jest dla wszystkich. Przywraca władzę nad złem, pozwalając postrzegać je jako dobrowolne, chociaż kiedyś było bezwolne, aby tym bardziej trzymać się od niego z daleka, nienawidzić namiętności i nie pozwalać, aby przechodziły w czyn. Kto ogranicza pokutę, wraca do dawnych przewinień. ${ }^{51}$ Kto kiedyś uwolnił się z namiętności, a następnie poddaje się nacierającemu złu, zaniedbując walkę i modlitwę, zostanie w konieczny sposób opanowany nie tylko przez to zło, ale i inne namiętności. Będzie pozbawiony pomocy Bożej, podda się tyranii rzeczy, którym wcześniej podlegał, oddając się jeszcze większemu złu. ${ }^{52}$

Ślady dawnych chorób moralnych pozostają w postaci pewnej skłonności do zła, od którego odstąpiło się w pewnym momencie. Tą podatnością jest niedobrowolna pamięć wcześniejszego zła. Jeśli nawet wyrzuci się z umysłu wszelkie dobrowolne zło, wtedy nadal jeszcze namiętność daje znać o sobie w postaci niedobrowolnego zła. Trzeba podjąć walkę przeciwko tym niejako mimowolnym namiętnościom, które występują z przyczyny pewnej szczególnej podatności

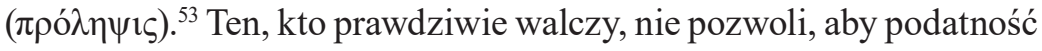
ta rozwinęła się ponownie w dobrowolną namiętność, podczas gdy zwycięzca niszczy ją całkowicie. ${ }^{54}$

Jak wcześniej stwierdziliśmy, dla autora trzy postawy człowieka stanowią o powstaniu namiętności: zapomnienie, niedbałość i nieświadomość. Jeśli chce je przezwyciężyć, powinien zająć się modlitwą i wrócić do siebie z pomocą Bożą, wejrzeć w głębię swego serca i odczuć te trzy potężne środki, którymi posługuje się diabeł. Temu trojakiemu złu przeciwstawne są następujące środki: zapomnieniu - pamięć dobrych dzieł, niedbałości - najszczersza gotowość,

\footnotetext{
${ }_{51}$ Zob. te n ż e, De paenitentia, 12.

52 Zob. tamże, 8.

53 Zob. te n ż e, De lege spirituali, 139, 921.

54 Zob. tamíe, 140.
} 


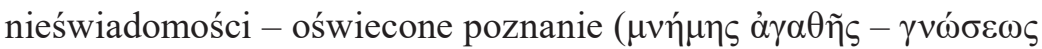

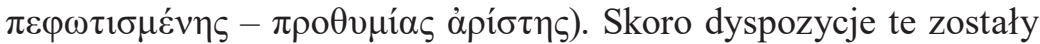
zdobyte nie na skutek pustej wiedzy czy przez samą dobrą wolę, ale dzięki mocy Bożej i pomocy Ducha Świętego, to taki człowiek dozna ratunku od niewoli zła. ${ }^{55} \mathrm{Na}$ przykład, kto nie pozyskał dzięki łasce Bożej poznania prawdy i bojaźni Bożej, ten dozna szkody nie tylko przez namiętności, ale i drastyczne zdarzenia. ${ }^{56}$

Pisarz podkreśla rolę medytacji w wyzwalaniu się z niewoli wad. Udziela na ten temat obszerniejszych wskazówek w piśmie $A d$ Nicolaum praecepta animae salutaria. Adresat pisma, Mikołaj, żali się, że ponad miarę dotyka go namiętność gniewu i pożądania. Prosi więc o słowo pouczenia i zachęty. Autor wskazuje na już przekazane adresatowi treści do rozmyślania, które będą użyteczne w połączeniu $\mathrm{z}$ ascezą, wiarą i łaską Bożą, jeśli przyjmujący naukę będzie starać się postępować zgodnie z rozumem i poznaniem Bożym. Należy podjąć gorliwszą i nieustanną walkę przeciw namiętnościom. ${ }^{57}$ Zaleca się nieustającą gorliwość w rozpamiętywaniu zbawczych wskazań i czynów Chrystusa, od czego odwodzi czy to ukryte zło, czy lekkomyślność. Należy spędzać czas pożytecznie i w duchu wdzięczności. Tego rodzaju dobre wspomnienia, które kłują niczym oścień serce, skłaniają do wyznania, pokory, dziękczynienia, gorliwości, zadośćuczynienia na różne sposoby i w ogóle cnoty. Dusza, która rozpamiętuje czyny Boga - miłośnika człowieka - zostaje uratowana z niejednego niebezpieczeństwa. ${ }^{58}$ Kiedy doznaje się braku czci ze strony ludzi, warto pomyśleć o czekającej chwale Bożej. Z jednej strony zapobiegnie się zmartwieniu i zamętowi, z drugiej - przygo-

55 Zob. t e n ż e, Ad Nicolaum praecepta animae salutaria, 13, 1049. Szerzej o roli pamięci, poznania i gorliwości w walce duchowej zob. E. F a u r e, Mémoire, connaissance et zèle dans le combat spirituel selon la Lettre à Nicolas attribuée à Marc le moine, Nouvelle Revue Théologique 139 (2017) nr 4, s. 605-618.

56 Zob. Mare k E r e m it a, De his qui putant se ex operibus iustificari, 181.

57 Zob. t e n ż e, Ad Nicolaum praecepta animae salutaria, 1, PG 65, 1029: oĩ

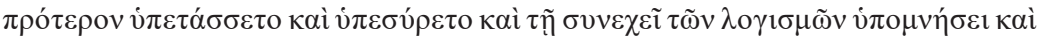

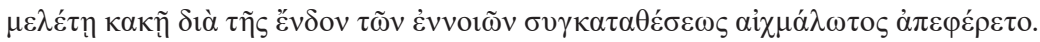

58 Zob. tamże, 2. 


\section{LEON NIEŚCIOR}

tuje się siebie na spotkanie z Panem w stanie wierności i bez nagany. ${ }^{59}$ Taką pobożną praktykę Marek nazywa ,szlachetnym rozważaniem”

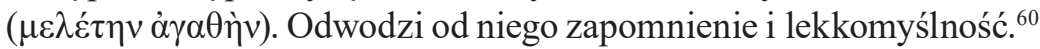
Duch, pomny na dzieła dokonane przez Boga, a jeszcze bardziej przez łaskę, zostaje przeniknięty miłością i tęsknotą. Dlatego Mikołaj ma pamiętać o dobrodziejstwach Boga w swoim osobistym życiu, a zwłaszcza o tym, że został uratowany, wraz z dwiema innymi osobami, podczas katastrofy statku zatopionego przez sztorm, kiedy razem z matką wracał do Konstantynopola po nawiedzeniu Ziemi Świętej. ${ }^{61}$

Autor często nawiązuje do kenozy Chrystusa i w medytacji nad nią dostrzega skuteczną broń w zwalczaniu namiętności. Rozważanie męki Pańskiej, co będą podkreślać pisarze średniowieczni, dobrze służy walce z grzechem. Jeśli kto chce pokonać gniew i pychę, musi mieć w pamięci uniżenie Syna Człowieczego, który zstąpił z wyżyn nieba i przyjął ludzki los. ${ }^{62}$ Kiedy rozważymy uniżenie się Chrystusa, to cała budowla niegodziwości, goryczy i gniewu, oparta na pysze, bez trudu, niejako sama przez się, zostanie zburzona. ${ }^{63}$ Wtedy uświadomimy sobie, że nikt nie może być prawdziwym chrześcijaninem, jeśli nie jest gotów nieść swego krzyża, a więc też przyjąć upokorzenie, wzgardę i krzywdę, a odrzucić ludzką chwałę, zaszczyty i przyziemne przyjemności. ${ }^{64}$

Marek Eremita podkreśla rolę upomnienia w zmaganiu się z namiętnościami. Kto ma wstręt do napominania, z góry poddaje się

59 Zob. te n ż e, De his qui putant se ex operibus iustificari, 61.

${ }_{60}$ Zob. te n ż e, Ad Nicolaum praecepta animae salutaria, 3, 1032.

${ }_{61}$ Zob. tamże, 6. Mikołaj utracił wtedy swoją matkę, która zginęła razem z całą załogą statku. Jego wychowaniem zajmie się niejaki Eleuter, który ukształtuje w nim postawę religijną, tak że Mikołaj zostanie mnichem. Autor listu zwraca się do niego jako do młodego mnicha; zob. O. H e s s e, Wstęp, w: M a r k u s E r e m it a, Asketische und dogmatische Schriften, Stuttgart 1985, s. 79.

${ }_{62}$ Zob. Mare k E r e m it a, Ad Nicolaum praecepta animae salutaria, 8.

${ }^{63}$ Zob. tamie, 10.

64 Zob. tamże, 3. 
namiętności, a kto je lubi, będzie czynił postęp. ${ }^{65}$ Kto budząc bojaźń w grzeszniku, wpoi w nim pewne reguły, ten sam nabędzie cnotę przeciwną wadzie, którą zwalczał u tamtego. ${ }^{66}$ Kto wspomina zło i w złej woli szydzi z drugiego, ten popadnie w tę samą namiętność zgodnie z duchowym prawem (Rz 7, 14). ${ }^{67}$ Jak żeglarze lubią żar słoneczny, który przeciwstawia się chłodom wiatru, tak ulegający namiętnościom, ale z nimi walczący, lubią naganę, która przeciwstawia się namiętnościom. ${ }^{68}$

Nasz pisarz nie wyobraża sobie ascezy bez pomocy Boga. Dość często pojawia się temat łaski i pomocy Bożej w pracy nad sobą. Autor wpisuje walkę z namiętnościami w dzieło odkupieńcze Chrystusa. Chrystus stał się do nas podobny we wszystkim oprócz grzechu, to jest namiętności $(\mathrm{Hbr} 4,15) \cdot{ }^{69}$ Kiedy pisarz stwierdza, że On w ciele i duchu przyjął wspólnotę z nami i ,poręczył za nasze namiętności”

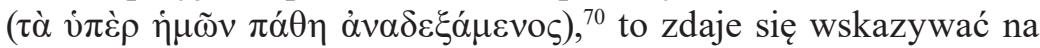
usprawiedliwienie, którego dostępuje w Nim chrześcijanin. Marek Eremita jest teologiem Ducha Świętego. Na tego, kto nienawidzi i pokonuje namiętności, zstępuje Duch Boży i oświeca, a na tego, kto im ulega, sprowadza zaciemnienie. ${ }^{71}$ Pokój, który przychodzi po wyzwoleniu się z namiętności, jest Jego dziełem. ${ }^{72}$

Pisząc w swoich dziełkach o namiętnościach, Marek Eremita miał za sobą długowiekową tradycję myśli ascetycznej. Dociekliwość prowadzi jednak mistrza ascezy do oryginalnych stwierdzeń na ten temat. W zapomnieniu o dobrych myślach, lekkomyślności

\footnotetext{
${ }_{65}$ Zob. t e n ż e, De lege spirituali, 152.

${ }_{66}$ Zob. te n ż e, De his qui putant se ex operibus iustificari, 171.

67 Zob. tamże, 171.

68 Zob. tamże, 69.

69 Zob. te n ż e, Ad Nicolaum praecepta animae salutaria, 9.

70 Zob. te n ż e, Disputatio cum quodam causidico, 20, resp. 14, 1100.

71 Zob. te n ż e, De his qui putant se ex operibus iustificari, 110.

72 Zob. te n ż e, De lege spirituali, 193.
} 


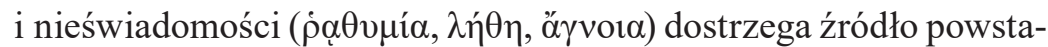
nia wielu namiętności. Wspólnym korzeniem namiętności jest skłonność w człowieku do szukania przyjemności (†்v $\delta \alpha \theta \varepsilon i ́ \alpha)$. Nasz pisarz doszukuje się w życiu teologalnym, określonym przez wiarę, nadzieję i miłość, zapoczątkowanym przez chrzest, podstawy niewinności moralnej człowieka, a w jego braku - przyczyny pleniącego się zła. Wskazuje na konkretne środki walki z namiętnościami. Zapomnieniu należy przeciwstawić pamięć dobrych dzieł, niedbałości - najszczerszą gotowość do walki, nieświadomości - oświecone poznanie. Autor podkreśla rolę medytacji, zwłaszcza dobrodziejstw Bożych oraz uniżenia się Chrystusa, w walce z wadami. Jako teolog Ducha Świętego, snuje refleksję o Jego roli w ascezie.

Leon NIEŚCIOR OMI

Słowa kluczowe: Marek Eremita; asceza; namiętności

Keywords: Mark the Ascetic; asceticism; passions

\section{Passions and struggle against them according to Mark the Ascetic Summary}

Writing in his works about passions, Mark the Ascetic had behind him a long-term tradition of ascetic thought. However, an inquisitiveness leads the Master of asceticism to original statements on this subject. In forgetting

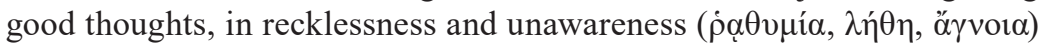
he sees the origin of many passions. The common root of passion is the human tendency to seek pleasure (i $\delta v \pi \alpha \theta \varepsilon i \alpha)$. Mark the Ascetic finds in the theologal life, which determined by faith, hope and love, and which is initiated by baptism, the basis of moral innocence of man. In the absence of this life, he sees the cause of the development of evil. He points to concrete measures to fight passions. The forgetting should be contrasted with the memory of good works, the negligence with the sincere readiness to fight, and the unawareness with the enlightened cognition. The author emphasizes the role of meditation, especially of God's favours and Christ's abasement, in the fight against faults. As a theologian of the Holy Spirit, he reflects on His role in asceticism. 